\title{
RESPON PENGEMBANGAN PERTANIAN ORGANIK TERHADAP PENDAPATAN USAHATANI PADI DI DESA BABATAN LINTANG KANAN KABUPATEN EMPAT LAWANG
}

\author{
(Agoes Thony)
}

\begin{abstract}
The purpose of this research is to: (1) Analyze the income and feasibility of organic rice farming developed in Babatan Village, Lintang Kanan Sub-district, Empat Lawang Regency, (2) To know the community response in the development of organic rice in Babatan Village, Lintang Kanan District, Empat Lawang District. This research was conducted in regency of Empat Lawang of South Sumatera Province. The determination of the location of the research is purposive or purposive, considering that in Desa Babatan Kecamatan Lintang Kanan, Empat Lawang regency is one of the villages that develops organic rice farming and the area has enough population in the research criteria. The data collection at the research location will be conducted in March 2015 until it is completed. The research found that average rice production yield is $1,419 \mathrm{~kg} /$ production with average price of organic rice $R p 10.000 / \mathrm{kg}$ so that the average revenue of $R p$ 14,191,200 / production is obtained. Average production cost incurred $R p$ 6.896.820 / production and earned an average income of $R p$ 7,294,380 / production. Judging from the amount of revenues greater than the total total cost incurred, the production of organic and inorganic paddy rice has a positive income so that it is financially profitable. The response of farmers to the development of organic rice in Babatan Village is dominated by medium response because the community is still in the learning stage in the effort of developing organic rice in Babatan Village, Empat Lawang Regency.
\end{abstract}

Key Words : Organic agriculture, Agribusiness Management, Income.

\section{PENDAHULUAN}

\section{A. Latar Belakang}

Pertanian organik merupakan sistem manajemen produksi yang bertujuan untuk produksi yang sehat dengan menghindari penggunaan kimia berbahan aktif dalam hal ini pupuk kimia maupun pestisida kimia untuk menghindari pencemaran udara tanah dan air juga hasil produksi pertanian pada khususnya. Selain itu, pertanian organik juga menjaga keseimbangan ekosistem dan sumberdaya alam yang terlibat langsung dalam proses produksi (Soetrisno L., 1998).

Sistem pertanian organik memberikan beberapa manfaaat diantaranya adalah :

1. Tanaman menjadi sehat, bebas dari bahan kimia aktif, residu, baik dari akibat oleh pestisida ataupun pemupukan.

2. Hasil produksi akan lebih sehat.

3. Menjadi pertanian yang mampu menjaga kelestarian alam dan menjaga keseimbangan ekosistem.

Hasil produksi pertanian organik diindonesia masih sedikit dibandingkan dengan hasil yang anorgnik, misalnya dari hasil perkebunan di Indonesia, masih sedikit perkebunan yang menggunakan sistem pertanian organik, sehingga hasil produksinya pun masih sedikit, yang mulai terus berkembang adalah tanaman pangan organik dan hortikultura, meskipun ada beberapa hasil dari pertanian tanaman pangan dan hortikultura yang belum tersertifikasi organik, namun dari penerapan sistem pertanian sudah menggunakan sistem pertanian organik yang diharapkan kedepannya meningkatkan kualitas produksi menjadi benarbenar organik dan juga meningkatkan hasil produksi dari segi kuantitas (Saleh, E. dkk. 2012).

Aspek yang perlu diperhatikan dalam sistem pertanian organik adalah pupuk organik dan pestisida organik (nabati), karena dalam sistem pertanian pupuk dan pestisida merupakan sarana produksi yang utama setelah benih. Penggunaan pupuk organik sangat menentukan arah sistem pertanian kedepannya, menjadi organik atau akan tetap menjadi pertanian konvensional, dalam hal konversi juga penggunaan pupuk organik akan menjadi hal yang perlu diperhatikan, untuk mengembalikan kesuburan tanah volume pupuk organik akan ditambah dengan tujuan untuk menyehatkan tanah dan membebaskan dari unsur residu. Penggunaan pestisida kimia nantinya akan kembali merusak keberlangsungan pertanian organik, dalam pengendalian hama menggunakan pestisida nabati atau pestisida organik.

Kondisi pengairan atau irigasi menjadi penentu juga dalam pertanian organik. Akan menjadi sia-sia apabila kita menerapkan pertanian organik sementara air yang mengaliri lahan kita banyak mengandung residu bahan kimia. 
Tentunya lahan kita akan beresiko tercemar zatzat tersebut. Pada akhirnya produk pertanian organik tidak steril dari racun-racun kimia (Marlina, 2012).

Untuk menghindari hal ini, lahan harus mempunyai pengairan langsung dari mata air terdekat. Jika tidak ada, air bisa diambil air dari saluran irigasi yang agak besar. Kadar residu kimia dalam saluran air yang besar biasanya sangat rendah, dan airnya masih bisa digunakan untuk pertanian organik. Hindari mengambil air dari limpahan kebun atau sawah konvensional. Selain itu, bisa juga dibuat unit pemurnian air sendiri. Air dari saluran irigasi ditampung dalam sebuah kolam buatan. Kemudian air keluaran kolam dipakai untuk mengairi padi sawah organik. Benih yang digunakan dalam padi sawah organik harus berasal dari benih organik. Apabila benih organik sulit didapatkan, untuk tahap awal bisa dibuat dengan memperbanyak benih sendiri.

Adapun caranya yaitu dengan membersihkan benih-benih tersebut dari residu pestisida. Untuk menjadikannya organik, tanam benih tersebut lalu seleksi hasil panen untuk dijadikan benih kembali. Gunakan kaidah-kaidah pemuliaan dan penangkaran benih pada umumnya. Jangan mengawetkan benih dengan pestisida, fungisida atau hormon-hormon sintetis. Gunakan metode tradisional untuk mengawetkannya. Benih yang dihasilkan dari proses ini sudah bisa dikatakan benih organik.

Hal yang perlu dicatat, benih hasil rekayasa genetika tidak bisa digunakan untuk sistem pertanian organik. Pertanian organik juga bisa menggunakan penyubur tanah atau disebut juga pupuk hayati. Penyubur tanah ini merupakan isolat bakteri-bakteri yang bisa memperbaiki kesuburan tanah. Saat ini pupuk hayati banyak dijual dipasaran seperti EM4, Biokulktur, dan lain-lain. Pupuk hayati juga bisa dibuat sendiri dengan mengisolasi mikroba dari bahan-bahan organik. Dalam fermentasi bahan-bahan tambang mineral alami seperti kapur dan belerang masih ditoleransi untuk digunakan pada pertanian organik. Berikut daftar bahan mineral yang bisa digunakan dalam pertanian organik yaitu Dolomit, Gipsum, Kapur khlorida, Batuan fosfat dan Natrium klorida.

Pengendalian hama dalam pertanian organik sebaiknya menerapkan konsep pengendalian hama terpadu. Hal-hal yang terlarang adalah menggunakan obat-obatan seperti pestisida, fungisida, herbisida dan sejenisnya untuk membasmi hama. Pengendalian organisme penganggu tanaman bisa memanfaatkan yaitu pemilihan varietas yang cocok, rotasi tanaman, menerapkan kultur teknis yang baik, seperti pengolah tanah, pemupukan, sanitasi lahan, dan lain-lain. Memanfaatkan musuh alami atau predator hama dan menerapkan eksosistem pertanian yang beragam, tidak monokultur.

Apabila terpaksa, misalnya terjadi ledakan hama atau penyakit, bisa digunakan juga pemberantasan hama dengan pestisida alami atau pestisida organik. Proses pencucian atau pembersihan produk hendaknya menggunakan air yang memenuhi standar baku mutu organik. Hindari air yang sudah tercemar zat-zat kimia sintetsis. Gunakan juga peralatan yang tidak terkontaminasi zat-zat kimia. Dalam penyimpanan dan pengangkutan produk organik sebaiknya tidak dicampur dengan produk non organik. Untuk memberikan nilai tambah, produk-produk organik dikemas dengan bahan yang ramah lingkungan dan bisa didaur ulang (Syamsudin, T. S., dan Aktaviyani, S. 2009).

Sumatera Selatan merupakan provinsi yang memiliki program lumbung pangan nasional, hal ini tidak terlepas dari tersedianya potensi sumber daya lahan yang cukup variatif, mulai dari lahan sawah irigasi, tadah hujan, rawa pasang surut, lebak dan lahan kering. Produksi padi Sumatera Selatan pada tahun 2012 yaitu sebesar 3.859.132 ton gabah kering giling (GKG) dengan jumlah penduduk $\quad 8.5428 .719 \quad$ jiwa konsumsi beras perkapita sebesar $105(\mathrm{~kg})$.

Kabupaten Empat Lawang merupakan salah satu Kabupaten di Provinsi Sumatera Selatan dengan Jumlah 10 Kecamatan diantaranya adalah Kecamatan Lintang Kanan, Muara Pinang, Pasemah Air Keruh, Pendopo, Talang Padang, Tebing Tinggi, Ulu Musi, Sikap Dalam, Saling dan Pendopo Barat. Sepuluh kecamatan tersebut memiliki hasil pertanian yang beragam. Kabupaten Empat Lawang kini mulai mengembangkan pertanian organik terutama pada tanaman padi, sebagian masyarakat membudidayakan padi organik yang dipandu oleh Penyuluh Pertanian. Namun, pada saat ini pertanian organik baru dikembangkan pada tiga kelompok tani namun masih banyak kendala dalam pengembangan padi organik di Kabupaten Empat Lawang.

\section{B. Rumusan Masalah}

1. Bagaimana tingkat pendapatan dan kelayakan usahatani padi organik di Desa Babatan 
Kecamatan Lintang Kanan Kabupaten Empat Lawang.

2. Bagaimana respon masyarakat dalam pengembangan padi organik di Desa Babatan Kecamatan Lintang Kanan Kabupaten Empat Lawang.

\section{Tujuan dan Kegunaan}

1. Menganalisis pendapatan serta kelayakan usahatani padi organik yang dikembangkan di Desa Babatan Kecamatan Lintang Kanan Kabupaten Empat Lawang.

2. Untuk mengetahui respon masyarakat dalam pengembangan padi organik di Desa Babatan Kecamatan Lintang Kanan Kabupaten Empat Lawang.

\section{Model Pendekatan}

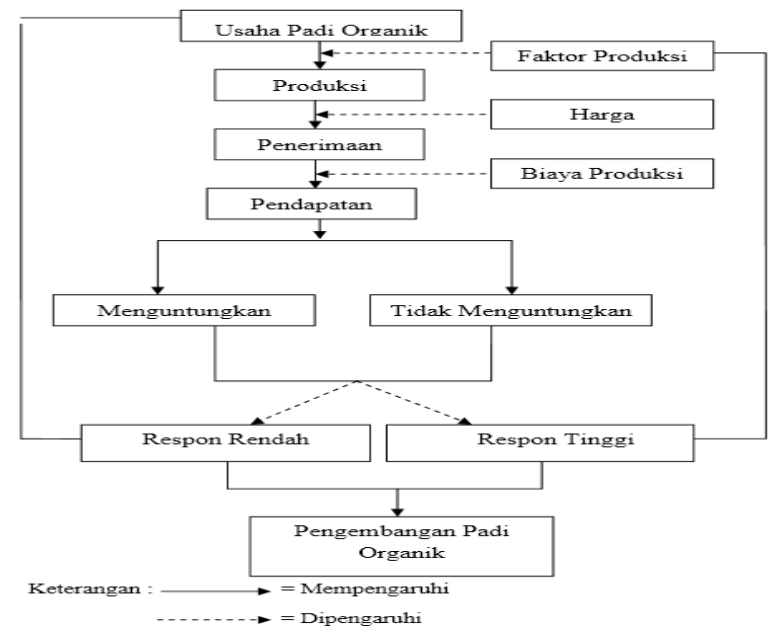

Gambar 1. Model pendekatan penelitian secara diagramatik

\section{METODOLOGI PENELITIAN}

\section{A. Tempat dan Waktu}

Penelitian ini telah dilaksanakan di Kabupaten Empat Lawang Provinsi Sumatera Selatan. Penentuan lokasi penelitian dilakukan secara purposive atau sengaja, dengan pertimbangan bahwa di Desa Babatan Kecamatan Lintang Kanan Kabupaten Empat Lawang adalah salah satu Desa yang mengembangkan usahatani padi organik serta wilayah tersebut memiliki jumlah populasi yang cukup dalam kriteria penelitian. Pengumpulan data dilokasi penelitian akan dilaksanakan pada Bulan Maret 2015 sampai dengan selesai.

\section{B. Metode Penelitian}

Menurut Nazir (2011), metode penelitian adalah metode yang dipilih berhubungan erat dengan prosedur alat, serta desain penelitian yang digunakan untuk memandu peneliti tentang urutan-urutan bagaimana penelitian dilakukan. Metode yang digunakan dalam penelitian ini adalah metode survei. Metode survei adalah penyelidikan yang diadakan untuk memperoleh fakta-fakta dari gejala-gejala yang ada dan mencari keterangan-keterangan secara faktual. Metode ini digunakan untuk mengetahui potensi dan kendala dalam pengembangan padi organik serta biaya yang digunakan petani berdasarkan data yang didapatkan dari petani sampel.

\section{Metode Penarikan Contoh}

Metode penarikan contoh yang digunakan dalam penelitian ini adalah metode sensus teknik penentuan sampel untuk tujuan tertentu saja. Metode Sensus adalah pengambilan sampel secara keseluruhan dari jumlah populasi yang ada. Jumlah sampel pada penelitian ini yaitu tiga kelompok tani setiap kelompok tani mempunyai 10 anggota kelompok maka dalam penentuan sampel diambil secara keseluruhan yaitu 30 sampel, karena 30 sampel dari kelompok tani ini benar-benar mengusahakan padi organik di Desa Babatan Kecamatan Lintang Kanan Kabupaten Empat Lawang.

\section{Metode Pengolahan Data}

Data yang diperoleh dari lapangan, diolah secara tabulasi dan matematis. Yang meliputi biaya produksi, penerimaan,dan pendapatan. Untuk menghitung besarnya biaya produksi dapat menggunakan rumus matematis sebagai berikut :

1) Untuk Menghitung Biaya Produksi dan Pendapatan

a) $\mathrm{BP}=\mathrm{BT}+\mathrm{BV}$

b) $\mathrm{Pn}=\mathrm{H} \times \mathrm{P}$

c) $\mathrm{Pd}=\mathrm{Pn}-\mathrm{Bp}$

Keteranagan :

$\mathrm{BP}=$ Biaya Produksi (Rp/Proses Produksi)

$\mathrm{BT}=$ Biaya Tetap $(\mathrm{Rp} /$ Proses Produksi $)$

$\mathrm{BV}=$ Biaya Variabel (Rp/Proses Produksi)

$\mathrm{Pn}=$ Penerimaan Total $(\mathrm{Rp} /$ Proses Produksi)

$\mathrm{P}=$ Hasil Produksi (Rp/Proses Produksi)

$\mathrm{H}=$ Harga (Rp/Proses Produksi)

$\mathrm{Pd}=$ Pendapatan

2) Untuk analisis tingkat pengembalian modal menggunakan rumus :

$$
\mathrm{ROI}=\frac{I}{T C} x 100
$$

Dimana :

I = Investasi 


\section{$\mathrm{TC}=$ Total Cost}

3) Untuk indikator respon petani dikelompokan kedalam interval kelas dengan pemberian skor 3 untuk kriteria tinggi, skor 2 untuk kriteria sedang dan skor 1 untuk kriteria rendah lalu dijelaskan secara diskriptif.

$$
\mathrm{NR}=\mathrm{NST}-\mathrm{NSR} \text { PI }=\mathrm{NR}: \mathrm{JIK}
$$

Keterangan :

$\mathrm{NR}=$ Nilai Range

$\mathrm{PI}=$ Panjang Interval Kelas

NST = Nilai Skor Tertinggi

JIK = Jumlah Interval Kelas

NSR = Nilai Skor Terendah

Perhitungan untuk interval kelas total respon petani adalah sebagai berikut :

$\mathrm{NST}=45$ (3 indikator $\mathrm{x} 5$ pertanyaan $\mathrm{x}$ bobot pertanyaan (3)

NSR $=15$ (3 indikator $\mathrm{x} 5$ pertanyaan $\mathrm{x}$ $\mathrm{JIK}=3$ bobot pertanyaan (1)

Perhitungan :

$$
\begin{array}{rlrl}
\mathrm{NR} & =\mathrm{NST}-\mathrm{NSR} & \mathrm{PI} & =\mathrm{NR}: \mathrm{JIK} \\
& =45-15=30 & & =30: 3=10
\end{array}
$$

Untuk interval kelas per indikator adalah :

$$
\begin{array}{rlrl}
\mathrm{NR} & =\mathrm{NST}-\mathrm{NSR} & \mathrm{PI} & =\mathrm{NR}: \mathrm{JIK} \\
& =15-5=10 & & =10: 3=3,33
\end{array}
$$

Untuk interval kelas per pertanyaan adalah :

$$
\begin{array}{rlrl}
\mathrm{NR} & =\mathrm{NST}-\mathrm{NSR} & \mathrm{PI} & =\mathrm{NR}: \mathrm{JIK} \\
& =3-1=2 & & =2: 3=0,67
\end{array}
$$

Tabel 1. Interval kelas untuk respon petani dalam rencana program agribisnis usaha pengembangan padi organik di Kabupaten Empat Lawang.

\begin{tabular}{lllll}
\hline No & $\begin{array}{l}\text { Nilai Interval Kelas } \\
\text { (Skor Total) }\end{array}$ & $\begin{array}{l}\text { Nilai Interval Kelas } \\
\text { (Per Indikator) }\end{array}$ & $\begin{array}{l}\text { Nilai Interval Kelas } \\
\text { (Per Pertanyaan) }\end{array}$ & Kriteria \\
\hline 1 & $15,00 \leq x \leq 25.00$ & $5,00 \leq x \leq 8,33$ & $1,00 \leq x \leq 1,67$ & Rendah \\
2 & $25,10<\mathrm{x} \leq 35.00$ & $8,33<\mathrm{x} \leq 11,66$ & $1,67<\mathrm{x} \leq 2,33$ & Sedang \\
3 & $35,10<\mathrm{x} \leq 45,00$ & $11,66<\mathrm{x} \leq 15,00$ & $2,33<\mathrm{x} \leq 3,00$ & Tinggi
\end{tabular}

Sumber: Data Olahan, 2015.

\section{HASIL DAN PEMBAHASAN}

\section{Analisis Biaya Usahatani Padi Organik}

Biaya adalah pengorbanan sumber ekonomi yang diukur dalam satuan uang yang telah terjadi atau kemungkinan akan terjadi untuk mencapai tujuan tertentu Shinta (2011). Biaya dalam kegiatan usahatani dikeluarkan oleh petani dengan tujuan untuk menghasilkan pendapatan yang tinggi bagi usahatani yang dikerjakan, dengan mengeluarkan biaya maka pertanian mengharapkan pendapatan yang setinggitingginya melalui peningkatan produksi.

Biaya tetap (Fixed Cost) Biaya yang relatif tetap jumlahnya dan harus dikeluarkan walaupun produk yang dihasilkan banyak atau sedikit. Biaya tidak tetap (Variable cost) Biaya tidak tetap yang sifatnya berubah-ubah tergantung dari besar kecilnya produksi yang dihasilkan. Dalam hasil penelitian dan padi organik di Desa Babatan Kecamatan Lintang Kanan kBupaten Empat Lawang yang dikelompokkan ke dalam biaya tetap di antaranya adalah sewa lahan, dan penyusutan alat. Sedangkan untuk biaya variabel terdiri dari biaya benih, pupuk, pestisida, dan tenaga kerja.

Berikut ini merupakan komponen biaya yang dikeluarkan oleh petani dalam kegiatan usahatani padi organik Di Desa Babatan Kecamatan Lintang Kanan adalah sebagai berikut: a) Biaya Tetap

\begin{tabular}{|c|c|c|}
\hline NO & $\begin{array}{c}\text { Komponen } \\
\text { Padi Organik }\end{array}$ & $\begin{array}{l}\text { Rata-rata } \\
\text { (Rp/LG) }\end{array}$ \\
\hline 1. & Sewa Lahan & 3.146 .667 \\
\hline 2. & Penyusutan Alat & 78.841 \\
\hline
\end{tabular}

Biaya tetap yang digunakan pada produksi padi organik diantaranya meliputi biaya sewa lahan, dan biaya penyusutan alat yang dapat dilihat pada tabel berikut :

Tabel 2. Rata-rata Biaya Tetap pada Usahatani Padi Organik.

Sumber: Data Olahan Primer, 2015.

Kegiatan usahatani responden padi organik Di Desa Babatan, dalam penggunaan input lahan sebagian besar memiliki status kepemilikan lahan sendiri, namun ada beberapa petani yang memiliki status kepemilikan lahan sewa, sehingga dalam kaidah usahatani semuanya dianggap sebagai lahan sewa. Karena untuk petani dengan status kepemilikan lahan sendiri juga melakukan pembayaran pajak lahan (Wibowo, 2011). Berdasarkan data di atas bahwa biaya rata-rata sewa lahan pada usahatani padi organik biaya yang dibutuhkan pada sewa lahan per luas garapan rata-rata memerlukan biaya $\mathrm{Rp}$ 3.146.667/0,49 ha.

Penyusutan biaya peralatan yang dihitung meliputi penyusutan peralatan diantaranya terdiri atas cangkul, sabit, ember, handsprayer, dan roli. Biaya rata-rata penyusutan alat yang digunakan saat proses produksi padi anorganik dalam satu kali musim tanam adalah Rp 78.841/MT. 
b) Biaya Variabel Usahatani Padi Organik

Biaya variabel adalah biaya yang timbul dari pemakaian input tetap dan biaya yang dikeluarkan untuk membuat satuan-satuan ouput Sugiarto, Teddy Herlambang, dkk (2010). Biaya variabel yang digunakan dalam kegiatan usahatani di Desa Babatan terdiri atas biaya benih, pupuk, pestisida, dan tenaga kerja. Besarnya biaya variabel yang dikeluarkan oleh petani dapat dilihat pada tabel berikut :

Tabel 3. Rata-rata Biaya Variabel Usahatani Padi Organik.

\begin{tabular}{llr}
\hline No & \multicolumn{1}{c}{ Komponen } & Padi Organik \\
\hline 1. & Benih & 130.167 \\
2. & Pupuk Padat & 154.167 \\
& Pupuk Organik Cair & 172.000 \\
& Penggunaan MOL & 71.667 \\
3. & Pestisida & 150.833 \\
4. & Tenaga Kerja & 1.404 .938 \\
\hline & Jumlah Total & 2.083 .772 \\
\hline
\end{tabular}

Sumber: Data Olahan Primer, 2015.

Berdasarkan hasil tabel diatas, dapat diketahui bahwa rata-rata penggunaan biaya variabel padi organik 2.083.772/0,49 ha, dengan biaya terbesar terdapat pada komponen tenaga kerja. Hal ini disebabkan karena dalam kegiatan usahatani terdapat beberapa urutan kegiatan diantaranya mulai dari kegiatan pengolahan tanah, penanaman, pemupukan, pengairan, penyemprotan, hingga panen dan pasca panen. Setiap kegiatan tersebut menggunakan jumlah tenaga kerja tenaga kerja yang tidak sedikit sehingga biaya yang dikeluarkan oleh petani juga besar untuk masing-masing kegiatan diatas. Untuk penjelasan secara umum berdasarkan rata-rata masing-masing biaya variabel akan dijelaskan sebagai berikut :

1. Benih

Penggunaan input benih dalam kegiatan usahatani, menggunakan benih dengan berbagai macam varietas antara petani yang satu dengan yang lainnya, berupa benih unggul atau benih turunan. Adapun benih yang digunakan responden padi organik diantaranya varietas ciherang, Ciliwung, , IR64, dengan harga benih per $\mathrm{kg}$ berkisar antara Rp. 10.000,- hingga Rp. 15.000,$/ \mathrm{kg}$ dalam kemasan $5 \mathrm{Kg}$ sehingga pada penggunaan benih untuk lahan 0,49 ha memerlukan benih $9,33 \mathrm{Kg}$ dan memerlukan biaya $\mathrm{Rp} 154.167 /$ ha dengan harga rata-rata $\mathrm{Rp}$ $13.867 / \mathrm{Kg}$.

2. Pupuk

Usahatani padi organik, pupuk yang digunakan oleh petani organik untuk menbudidayakan tanamannya adalah dengan menggunakan pupuk kandang atau bokashi. Bokashi ini dibuat dari berbagai campuran bahan organik yang terdapat di alam, seperti pupuk kandang (kotoran hewan atau urin hewan), daundaunan hijau,dan sampah dapur. Bila ditambahkan campuran molase (air gula), EM-4 , dan air dalam proses dekomposisi maka hasilnya disebut pupuk organik cair. Rata-rata penggunaan pupuk organik cair (POC) yang digunakan petani di Desa Babatan adalah 2,4lt/0,39LG dengan biaya $\mathrm{Rp}$ 144.000/MT.

Pupuk kandang yang digunakan petani padi organik rata-rata adalah $147 \mathrm{~kg} / 0,49$ ha dengan

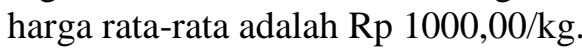

Petani padi organik menggunakan pupuk daun sebagai pupuk pelengkap, yaitu menggunakan mikro organisme lokal (MOL). Penggunaan MOL dilakukan petani untuk menambah jumlah unsur hara yang dibutuhkan oleh tanaman. MOL ini digunakan dengan cara disemprotkan menggunakan handsprayer. Pada umumnya MOL dibuat sendiri oleh petani karena menggunakan bahan-bahan organik yang mudah ditemukan di lingkungan.

Berdasarkan data yang diperoleh, kebutuhan MOL yang digunakan rata-rata sebesar 2,32 Lt/0,39 ha biaya $\mathrm{Rp} 58.014,71$ per luas garapan dalam satu kali musim tanam. Pupuk pelengkap cair digunakan sebagai zat pengatur tumbuh dengan penggunaan rata-rata $1.68 \mathrm{lt}$ dengan biaya rata-rata $\mathrm{Rp} 59.558,82$ per luas garapan dalam satu kali musim tanam.

\section{Pestisida}

Pengendalian hama dan penyakit pada usahatani organik tidak boleh menggunakan pestisida kimia. Hal ini dikarenakan dapat berpengaruh terhadap kualitas beras organik yang dihasilkan. Oleh karena itu, untuk pengendalian hama dan penyakitnya, para petani organik melakukannya dengan cara pengendalian fisik secara mekanis ketika hama telah mencapai level yang melebihi batas, metode pengendalian secara mekanis adalah pilihan utama yang harus dilakukan. Pengendalian mekanis mencakup pemungutan hama dengan tangan, menggunakan pelindung, jebakan, vakum, dan pembajakan tanah.

Pengendalian hama biologis secara alami hama memiliki predator dan parasit yang dapat digunakan untuk mengendalikan hama dengan dampak lingkungan yang minimum. Insektisida biologis yang berasal dari mikroorganisme (misal Bacillus thuringiensis) juga dapat digunakan. 
Pestisida merupakan cara terakhir yang dapat digunakan pada waktu tertentu pada siklus hidup hama. Berbagai pestisida yang berasal dari senyawa tumbuhan alami seprti nikotin dan piretrum telah tersedia dan dinilai tidak membahayakan lingkungan. Penerapan pestisida harus spesifik pada lokasi di mana hama berada sehingga penerapan pestisida dapat lebih efisien dan tidak mengganggu ekologi. Rata-rata pestisida nabati (pestisida organik) dalam pengguaan selama musim tanam memerlukan 6,03Lt/0,49 ha dengan biaya rata-rata $\mathrm{Rp} 150.833$ per musim tanam.

\section{Tenaga Kerja}

Menurut Rachmiyanti (2009), tenaga kerja merupakan salah satu faktor produksi yang memiliki pengaruh besar terhadap biaya usahatani. Oleh karena itu dalam penggunaannya petani harus memperhitungkannya. Kebutuhan tenaga kerja dalam satu musim tanam yang digunakan petani padi organik di Desa Babatan pada umumnya relatif sama. Namun kebutuhan tenaga kerja pada beberapa kegiatan dalam usahatani padi padi organik berbeda. Berikut adalah tabel penggunaan tenaga kerja selama musim tanam padi anorganik dan padi organik di Desa Babatan.

Tabel 4. Rata-rata Tenaga Kerja Usahatani Padi Per Hektar Pada Musim Tanam September-Janurai 2015.

\begin{tabular}{|c|c|c|}
\hline No & $\begin{array}{c}\text { Penggunaan Tenaga Kerja Selama Musim } \\
\text { Tanam }\end{array}$ & Padi Organik \\
\hline 1. & Pengolahan Lahan & 461.750 \\
\hline 2. & Penanaman & 295.000 \\
\hline 3. & Penyiangan & 116.875 \\
\hline 4. & Pemupukan & 148.000 \\
\hline 5. & Penyemprotan & 148.000 \\
\hline 6. & Penyulaman & 35.208 \\
\hline 7. & Konsumsi & 230.938 \\
\hline 8. & Biaya Bawon & 1.106 .250 \\
\hline
\end{tabular}

Sumber: Data Olahan Primer, 2015.

Berdasarkan data hasil tabel diatas, dapat diketahui bahwa jumlah biaya terbesar ada pada pengolahan lahan, usahatani dalam kegiatan pengolahan lahan dengan biaya sebesar $\mathrm{Rp}$ 461.750/ha pada padi organik. Hal ini disebabkan karena kegiatan pengolahan lahan padi organik biasanya responden mengerjakan orang lain untuk mengolah lahan sawah yang akan ditanami padi. Sedangkan biaya tenaga kerja yang terkecil terdapat dalam kegiatan penyulaman, hal ini disebabkan karena dalam kegiatan penyulaman biasa dilakukan sendiri oleh petaninya secara langsung, biasanya yang melakukan penyulaman adalah wanita sehingga upah yang diberikan sesuai dengan harian kerja wanita (HKW) di Desa Babatan yaitu Rp 50.000/HKW. Biaya rata-rata pada tenaga penyulaman pada padi organik $\mathrm{Rp}$ 35.208/HKW.

Total rata-rata biaya tenaga kerja dalam kegiatan usahatani padi organik di Desa Babatan adalah Rp. 2.542.201/0,49 ha . Penjelasan secara lengkap mengenai rata-rata biaya tenaga kerja yang dikeluarkan oleh petani dapat dilihat pada lampiran, sedangkan penjelasan secara singkat adalah sebagai berikut :

a) Pengolahan Lahan

Kegiatan yang dilakukan dalam pengolahan lahan diantaranya adalah pembersihan lahan dari rumput liar/semak belukar, pengolahan tanah, kemudian lahan siap untuk ditanami. Penulis menghitung tenaga pengolahan lahan dari tenaga tamping sampai dengan cabut benih dan garis tanam. Rata-rata jumlah tenaga kerja setiap petani terdiri 4,03/HOK petani padi organik, rata-rata jasa tenaga kerja pengolahan lahan padi organik Rp 461.750/0,49 ha.

b) Penanaman

Kegiatan penanaman benih yang dilakukan oleh sebagian besar petani di Desa Babatan dilakukan oleh tenaga kerja borongan dengan biaya $\mathrm{Rp}$ 600.000/0,49 ha, dengan rata-rata jumlah tenaga kerja adalah 6 HOK per luas garapan dan rata-rata biaya yang dikeluarkan responden biaya rata-rata upah tenaga kerja perluas garapan adalah $\mathrm{Rp} 2.95 .000 / 0,49$ ha pada setiap musim tanam di Desa Babatan.

c) Penyiangan

Penyiangan gulma maupun tanaman pengganggu tanaman utama pada lokasi penelitian, dilakukan satu kali selama satu musim tanam, tergantung dari banyaknya tanaman pengganggu yang ada. Rata-rata jumlah tenaga kerja yang digunakan dalam kegiatan penyiangan padi organik adalah sebanyak 2,34 HOK dengan ratarata biaya yang dikeluarkan petani pada kegiatan tersebut sebesar Rp. 116.875/0,49 ha.

\section{d) Pemupukan}

Kegiatan pemupukan dalam usahatani padi di Desa Babatan dilakukan oleh petani sendiri maupun bantuan tenaga kerja orang lain, namun hanya sebagian kecil saja tenaga kerja orang lain yang digunakan. Pemberian pupuk dilakukan sebanyak dua sampai dengan 3 kali dalam satu kali musim tanam, yaitu pada usia padi 10 hari 
setelah tanam (hst), 15 hst, dan 25 hst. Jumlah rata-rata tenaga kerja dalam kegiatan pemupukan. Jumlah rata-rata tenaga kerja pemupukan padi organik 1,23 HOK dengan rata-rata biaya $\mathrm{Rp}$ 148.000/LG.

\section{e) Penyemprotan}

Penyemprotan dalam kegiatan usahatani padi adalah kegiatan yang dilakukan oleh petani untuk kepentingan pengendalian hama penyakit yang ada. Ketika padi telah mencapai umur 25 hst, mulai terdapat hama maupun penyakit yang menyerang tanaman. Petani menggunakan pestisida pada kegiatan penyemprotan hama dan penyakit yang menyerang tanaman padi, kegiatan penyemprotan pestisida yang dilakukan petani di Desa Babatan sebanyak 2 sampai dengan 3 kali selama musim tanam. Jumlah tenaga kerja ratarata yang digunakan selama penyemprotan padi organik sebanyak 2,47 HOK dan biaya yang dikeluarkan adalah sebesar Rp 148.000/ 0.49 ha.

\section{f) Penyulaman}

Kegiatan penyulaman benih padi yang dilakukan oleh sebagian besar petani di Desa Babatan dilakukan oleh tenaga kerja wanita dengan biaya $\mathrm{Rp} 50.000 / \mathrm{HKW}$, dengan rata-rata jumlah tenaga kerja 0,70 HOK per luas garapan dan rata-rata biaya yang dikeluarkan oleh responden sebesar Rp 35.208/0,49 ha.

g) Panen

Kegiatan panen merupakan kegiatan yang membutuhkan jumlah tenaga kerja yang paling banyak dalam kegiatan usahatani, dalam melakukan kegiatan panen produksi gabah, sebagian besar petani padi di Desa Babatan petani padi organik untuk membantu tenaga perontok padi menggunakan teknik panen yang modern dengan bantuan tenaga mesin treser.

Rata-rata jumlah tenaga kerja yang diperlukan dalam kegiatan panen ini sebanyak 8,99 HOK dengan rata-rata biaya yang dikeluarkan oleh petani adalah biaya konsumsi dan bawon, untuk konsumsi Rp. 230.938/0,49ha dan biaya Bawon Rp 2.250.000/ha jadi biaya bawon rata-rata $\mathrm{Rp} 1,106,250 / \mathrm{LG}$. Panen padi organik petani langsung menjual berasnya pada gapoktan Mitra Mandiri dengan harga beras Rp $10.000 / \mathrm{kg}$, karena beras organik diolah oleh GAPOKTAN Mitra Mandiri di Desa Babatan Kecamatan Lintang Kanan Kabupaten Empat Lawang.

\section{Analisis Pendapatan Padi Organik}

Petani padi organik menjual gabah kering giling (GKG), tetapi dikelola oleh GAPOKTAN
Mitra Mandiri, gabah kering giling (beras) dipasarkan oleh gapoktan Mitra Mandiri dalam bentuk kemasan sehingga mempunyai nilai jual yang lebih yaitu dengan harga Rp 10.000/kg beras. Besarnya rata-rata pendapatan yang diterima oleh setiap petani reponden dalam kegiatan usahatani yang telah dilakukan dapat dilihat pada tabel berikut :

Tabel 5. Rata-rata Pendapatan Usahatani Padi Per Hektar Pada Musim TanamSeptember 2014-Januari 2015.

\begin{tabular}{llcr}
\hline NO & \multicolumn{1}{c}{ Uraian } & Satuan & Nilai \\
\hline 1. & Produksi Beras & Kg/Produksi & 1.419 \\
2. & Harga Beras & $\mathrm{Kg}$ & 10.000 \\
3. & Penerimaan & Rp/ Produksi & 14.191 .200 \\
4. & Biaya Produksi & Rp/ Produksi & 6.896 .820 \\
5. & Pendapatan & Rp/ Produksi & 7.294 .380 \\
6. & ROI & $\%$ & 105
\end{tabular}

Sumber: Data Olahan Primer, 2015.

Berdasarkan tabel di atas rata-rata hasil produksi beras sebesar $1.419 \mathrm{~kg} /$ produksi dengan harga rata-rata beras organik $\mathrm{Rp} 10.000 / \mathrm{kg}$ sehingga diperoleh penerimaan rata-rata $\mathrm{Rp}$ 14.191.200/produksi. Rata-rata biaya produksi yang dikeluarkan $\mathrm{Rp}$ 6.896.820/ produksi dan memperoleh pendapatan rata-rata sebesar $\mathrm{Rp}$ 7.294.380/produksi. Dilihat dari jumlah penerimaan yang lebih besar dari jumlah biaya total yang dikeluarkan, maka produksi padi organik dan padi anorganik memiliki pendapatan yang positif sehingga menguntungkan secara finansial.

Analisis ROI merupakan tingkat pengembalian modal dimana ROI pada usaha usahatani padi organik sebesar $105 \%$, artinya bahwa setiap Rp 100.000,- modal usaha yang digunakan akan kembali sebesar Rp 105.000 dalam satu kali usaha.

\section{Analisis Respon Penggembangan Padi Organik}

Berdasarkan analisis respon pada pengembangan padi organik di Desa Babatan Kecamatan Lintang Kanan dari hasil perhitungan berdasarkan pertanyaan yang diberikan peneliti kepada anggota kelompok tani yang bergabung dengan Gapoktan Mitra Mandiri memberikan respon sedang pada pengembangan padi organik di Desa Babatan.

Berdasarkan table dibawah ini respon pada pengembangan padi organik di Desa Babatan 
didominasi oleh respon sedang karena banyak petani kurang setuju pada pernyataan kesanggupan karena mereka belum mampu untuk melaksanaakan pada kriteria kesanggupan. Berdasarkan umur rata-rata dalam pengembangan padi organik yaitu 43 Tahun, luas lahan yang digunakan rata-rata adalah 0,49 ha, pendapatan rata-rata $\mathrm{Rp}$ 7.297.829/prodkasi, dalam kegiatan pengembangan padi organik memiliki hasil kriteria respon sebanyak 4 untuk kriteria tinggi dan 26 untuk kriteria sedang.

Tabel 6. Analisis Respon Petani Terhadap Pengembangan Padi Organik.

\begin{tabular}{|c|c|c|c|c|c|c|}
\hline \multirow[b]{2}{*}{ No } & \multicolumn{2}{|c|}{ Umur } & \multirow{2}{*}{$\begin{array}{l}\text { Luas } \\
\text { Lahan }\end{array}$} & \multirow{2}{*}{$\begin{array}{l}\text { Pendapatan } \\
\text { Padi Organik }\end{array}$} & \multirow{2}{*}{$\begin{array}{l}\text { Jumlah } \\
\text { Respon }\end{array}$} & \multirow{2}{*}{$\begin{array}{l}\text { Kriteria } \\
\text { Respon }\end{array}$} \\
\hline & Petani & Tahun & & & & \\
\hline 1 & M. Haris & 45 & 1,00 & $13.132 .750,00$ & 35 & Tinggi \\
\hline 2 & Santi & 70 & 0,75 & $9.104 .333,33$ & 37 & Tinggi \\
\hline 3 & Sunardi & 51 & 0,25 & $3.399 .069,44$ & 34 & Sedang \\
\hline 4 & M.Redi & 40 & 0,25 & $2.907 .472,22$ & 36 & Tinggi \\
\hline 5 & Devi & 45 & 1,00 & $15.879 .236,11$ & 25 & Rendah \\
\hline 6 & M.Irsan & 38 & 0,25 & $3.393 .583,33$ & 40 & Tinggi \\
\hline 7 & Antoni & 36 & 0,50 & $6.906 .472,22$ & 29 & Sedang \\
\hline 8 & Menen & 50 & 0,50 & $8.021 .138,89$ & 15 & Rendah \\
\hline 9 & Marhain & 43 & 0,50 & $7.685 .333,33$ & 31 & Sedang \\
\hline 10 & Haryadi & 55 & 0,25 & $4.029 .888,89$ & 34 & Sedang \\
\hline 11 & M.Yusan & 46 & 0,50 & $7.525 .444,44$ & 33 & Sedang \\
\hline 12 & Suprianto & 44 & 0,25 & $3.927 .444,44$ & 32 & Sedang \\
\hline 13 & Mulyadi & 44 & 0,25 & $4.035 .000,00$ & 30 & Sedang \\
\hline 14 & Unasa & 43 & 0,50 & $6.672 .777,78$ & 33 & Sedang \\
\hline 15 & Lukman & 44 & 0,75 & $10.236 .583,33$ & 34 & Sedang \\
\hline 16 & Mukhlan & 45 & 0,50 & $8.488 .847,22$ & 29 & Sedang \\
\hline 17 & Dik & 35 & 0,25 & $4.510 .972,22$ & 33 & Sedang \\
\hline 18 & Sarman & 58 & 0,50 & $7.500 .666,67$ & 27 & Sedang \\
\hline 19 & Mingan & 38 & 0,25 & $3.810 .097,22$ & 33 & Sedang \\
\hline 20 & Petriansah & 35 & 0,50 & $8.773 .027,78$ & 33 & Sedang \\
\hline 21 & Erhami & 40 & 1,00 & $17.196 .222,22$ & 33 & Sedang \\
\hline 22 & Edi Maryanto & 45 & 0,50 & $6.605 .916,67$ & 27 & Sedang \\
\hline 23 & Yayan & 42 & 0,50 & $8.134 .916,67$ & 33 & Sedang \\
\hline 24 & Jupri & 50 & 0,25 & $4.484 .861,11$ & 34 & Sedang \\
\hline 25 & Dedi & 37 & 0,75 & $9.219 .916,67$ & 33 & Sedang \\
\hline 26 & Evi & 36 & 0,25 & $3.525 .263,89$ & 33 & Sedang \\
\hline 27 & Hendri Andri & 40 & 0,50 & $8.632 .083,33$ & 27 & Sedang \\
\hline 28 & Buzar & 42 & 0,50 & $7.625 .472,22$ & 34 & Sedang \\
\hline 29 & Nawi & 45 & 0,25 & $3.858 .583,33$ & 29 & Sedang \\
\hline 30 & Latif & 35 & 0,75 & $9.608 .027,78$ & 32 & Sedang \\
\hline$\overline{\mathrm{Y}}$ & & 1317 & 14,75 & 218.831 .403 & 948 & \\
\hline$\Sigma$ & & 43,9 & 0,49 & 7.294 .380 & 32 & \\
\hline
\end{tabular}

Sumber: Data Olahan Primer, 2015.

\section{IV.KESIMPULAN DAN SARAN}

\section{A. Kesimpulan}

Berdasarnya hasil penelitian dan analisis yang telah dilakukan, maka dapat ditarik kesimpulan sebagai berikut:

1. Rata-rata hasil produksi beras sebesar 1.419 $\mathrm{kg} /$ produksi dengan harga rata-rata beras organik Rp 10.000/kg sehingga diperoleh

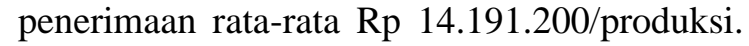
Rata-rata biaya produksi yang dikeluarkan $\mathrm{Rp}$ 6.896.820/ produksi dan memperoleh pendapatan rata-rata sebesar $\mathrm{Rp}$ 7.294.380/produksi. Dilihat dari jumlah penerimaan yang lebih besar dari jumlah biaya total yang dikeluarkan, maka produksi padi organik dan padi anorganik memiliki pendapatan yang positif sehingga menguntungkan secara finansial.

2. Respon petani terhadap pengembangan padi organik di Desa Babatan didominasi oleh respon sedang karena masyarakat masih dalam tahap belajar dalam upaya pengembangan padi organik di Desa Babatan Kabupaten Empat Lawang.

\section{B.Saran}

Berdasarkan hasil pembahasan dan kesimpulan yang ada di atas maka saran yang dapat diberikan oleh peneliti adalah:

1. Permasalahan kurang optimalnya penggunaan benih, pupuk, pestisida, dan tenaga kerja pada padi padi organik dapat diatasi dengan melakukan manajemen atau pengaturan pada pengunaan benih, pupuk, pestisida dan tenaga kerja yang disesuaikan dengan standar kebutuhan yang direkomendasi oleh penyuluh pertanian di Desa Babatan .

2. Pertanian organik diharapkan memberikan respon positf pada masyarakat untuk pengembangannya secara lebih lanjut menuju pertanian pangan bebas pestisida dan pertanian organik dapat memberikan kentungan secara global.

\section{DAFTAR PUSTAKA}

Apriantono, Anton. 2007. Konsep Pembangunan Pertanian. (Online). htpp://www.deptan.go.id/renbangtan/Konse p_Pembangunan_Pertanian. pdf). Diakses 17 Desember 2014.

BPS. 2013. Pedoman Teknis Sekolah Lapangan Pengolahan Tanaman Terpadu (SLPTT) Tahun 2013. (http://litbang.deptan.go.id/ind/pdf), diakses 17 Desember 2014.

Firdaus. 2009. Manajemen Agribisnis. Bumi Aksara. Jakarta.

Gitosudarmo, 2005. Teknik Proyeksi Bisnis. BPFE. Yogyakarta.

Hakim, A.N. 2003. Fakor Input dan Ouput Pada Produksi.http//www.

Konsep_input_dan_output.com. diakses pada 27/12/2013.

Hernanto, F. 1997. Ilmu Usahatani. Penebar Swadaya . Jakarta.

Hernanto, F. 2004. Ilmu Usahatani. Penebar Swadaya . Jakarta.

Ibrahim, Y. 2009. Study Kelayakan Bisnis. Ryneca Citra. Jakarta.

Kadariah, L. Karlina dan Gray, C. 1999. Pengantar Evaluasi Proyek. Fakultas Ekonomi Universitas Indonesia. Jakarta. 104 halaman.

Kartasapoetra, A.G. 2004. Manajemen Pertanian. Gramedia : Jakarta. 
Kordi. 2010. Budidaya Ikan Patin di Kolam Terpal. Lily Publisher. Yogyakarta.

Kotler, P. 2002. Manajemen Pemasaran, Prenhallindo. Jakarta.

Nazir, M. 2011. Metode Penelitian. Ghalia Indonesia. Bogor.

Nuraini. 2002. Pengantar Manajemen Agribisnis. Penebar Swadaya. Jakarta.

Notorianto, Dipo. 2011. Analisis Efisiensi Penggunaan Faktor-faktor Produksi Padi Organik dan Padi Anorganik. Skripsi. Ilmu Ekonomi Pembangunan. Fakultas Ekonomi. Universitas Diponegoro. Semarang. Diakses 22 April 2013.

Pramono. H. P. 2007. Budidaya 8 Jenis Tanaman Pangan. Jakarta: Penebar Swadaya.

Rachmiyanti, Inggit. 2009. Analisis Perbandingan Usahatani Padi Organik Metode System Of Rice Intensification (SRI) dengan Padi Konvensional. Skripsi pada Jurusan Ekstensi Manajemen Agribisnis Fakultas Pertanian Instistut Pertanian Bogor. Bogor. (tidak dipublikasikan).
Saleh, E. dkk. 2012. Budidaya Padi Di Dalam Polibag Dengan Irigasi Bertekanan Untlik Antisipasi Pesatnya Perubahan Fungsi Lahan Sawah. Teknotan 6(1): 692-699.

Soetrisno L. 1998. Pertanian pada Abad ke 21. Jakarta: Direktorat Jenderal Pendidikan Tinggi Departemen Pendidikan dan Kebudayaan.

Sutanto, Rachman. 2002. Pertanian Organik. Kanisius. Yogyakarta.

Syamsudin, T. S., dan Aktaviyani, S. 2009. Penerapan Pemupukan Pada Pertanian Padi Organik Dengan Metode System Of Rice Intensification (Sri) Di Desa Sukakarsa Kabupaten Tasikmalaya. Agroland 16 (1): 1 -8 .

Wibowo, S. Larasati. 2012. Analisis Efisiensi Alokatif Faktor-Faktor Produksi Dan Pendapatan Usahatani Padi (Oryza Sativa L.). Skripsi pada Jurusan Sosial ekonomi Pertanian Program Agribisnis Universitas Brawijaya Malang. Malang. (tidak dipublikasikan). 